\title{
Inne oblicza ostrych zespołów wieńcowych - kardiomiopatia takotsubo
}

\section{Other faces of acute coronary syndromes - takotsubo cardiomyopathy}

\author{
Aleksandra Ewa Jarecka ${ }^{1}$, Elżbieta Borowiecka ${ }^{2}$ \\ ${ }^{1}$ Oddział Chorób Wewnętrznych Nowodworskiego Centrum Medycznego w Nowym Dworze Mazowieckim \\ ${ }^{2}$ Klinika Chorób Wewnętrznych i Kardiologii Szpitala Klinicznego Dzieciątka Jezus w Warszawie
}

\section{Streszczenie}

Kardiomiopatia takotsubo jest rzadko występującą, bardzo ciekawą jednostką chorobową o nieznanym do dziś podłożu. Objawia się najczęściej typowymi dolegliwościami stenokardialnymi skojarzonymi z przewlekłym i ostrym stresem. Dotyczy zwykle białych kobiet w wieku okołomenopauzalnym. Podstawą diagnozy jest stwierdzenie dość szybko ustępujących typowych zmian w elektrokardiogramie i echokardiografii serca przy braku istotnych odchyleń w obrazie koronarograficznym. Rokowanie zwyklej jest pomyślne.

Słowa kluczowe: kardiomiopatia, takotsubo, stres

(Folia Cardiologica 2015; 10, 5: 370-373)

\section{Wstęp}

Opisany po raz pierwszy w 1991 roku przez Dote i Sato zespół takotsubo jest nazywany inaczej zespołem balotującego koniuszka, zespołem złamanego serca, kardiomiopatia stresową czy kardiomiopatią bańkowatą [1, 2]. Zespół ten jest klasyfikowany jako kardiomiopatia nabyta wywołana stresem. Nazwa zespołu takotsubo pochodzi od nazwy tradycyjnego japońskiego naczynia służącego do połowu ośmiornic. Naczynie to, o charakterystycznym bańkowatym kształcie, przypomina kształtem serce pacjenta chorego na zespół opisany przez japońskich autorów.

Zespół takotsubo częściej występuje u kobiet (95\% przypadków), w wieku okołomenopauzalnym, poddanych działaniu silnego stresu, zarówno psychicznego, jak i fizycznego. U niewielkiej liczby pacjentów nie udaje się określić czynnika stresowego [3]. Etiologia tej kardiomiopatii do dziś pozostaje niejasna.

\section{Opis przypadku}

Kobieta w wieku 75 lat została przyjęta na szpitalny oddział ratunkowy szpitala powiatowego z powodu nawracających od około 3 godzin dolegliwości stenokardialnych. W wywiadach stwierdzono ponadto: nadciśnienie tętnicze, nieczynny hormonalnie gruczolak prawego nadnercza, stan po dwóch udarach niedokrwiennych mózgu. Od 4 miesięcy chora była narażona na silny stres związany z wykonywaną pracą i problemami rodzinnymi.

W badaniu przedmiotowym przy przyjęciu do szpitala stwierdzono: miarową czynność serca 71/min, czyste tony, ciśnienie tętnicze o wartości 145/90 mm Hg, niewielki zastój w krążeniu małym. Nie wykazano zauważalnych odchyleń ze strony innych narządów. W zapisie elektrokardiograficznym (EKG) wykazano miarowy rytm zatokowy 58/min, odchylenie osi elektrycznej serca w lewo, blok przedniej odnogi pęczka Hisa (LAH, left anterior

Adres do korespondencji: lek. Aleksandra Ewa Jarecka, Oddział Chorób Wewnętrznych, Nowodworskie Centrum Medyczne, ul. Miodowa 2, 05-100 Nowy Dwór Mazowiecki, e-mail: a.e.jarecka@gmail.com 


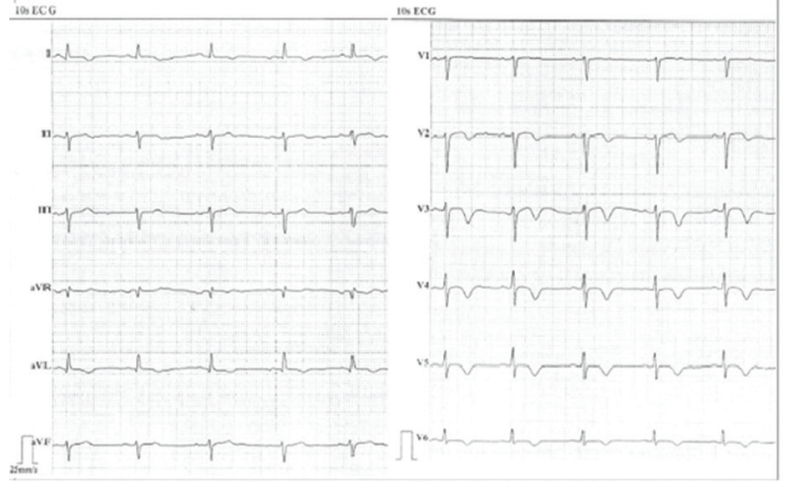

Rycina 1. Zapis elektrokardiograficzny przy przyjęciu pacjentki do szpitala

hemiblock), uniesienia odcinka ST w odprowadzeniach V2-V3, głęboko ujemne załamki T w odprowadzeniach V3-V5 (ryc. 1). Odchylenia w badaniach laboratoryjnych były następujące: stężenie potasu 3,4 mmol/L, stężenie ultraczułej troponiny $2,88 \mathrm{ng} / \mathrm{ml}$, wartość frakcji sercowej kinazy kreatynowej (CK-MB, creatine kinase myocarial band) 3,9 ng/dl.

Na podstawie objawów klinicznych, biochemicznych i elektrokardiograficznych u pacjentki wstępnie rozpoznano ostry zespół wieńcowy z uniesieniem odcinka ST i przekazano ją w celu dalszego leczenia na oddział kardiologii inwazyjnej w innym szpitalu. W wykonanej tam koronarografii w rzucie tętnic wieńcowych stwierdzono pojedyncze zwapnienia, bez zmian istotnych hemodynamicznie. Ponadto stwierdzono cechy zwolnionego przepływu przez naczynia nasierdziowe. W przeprowadzonym badaniu echokardiogra- ficznym wykazano akinezę koniuszka i segmentów koniuszkowych wszystkich ścian; frakcja wyrzutowa (EF, ejection fraction) wynosiła 45\%. Nie stwierdzono obecności wad zastawkowych ani cech płynu w worku osierdziowym. Uzupełniono diagnostykę laboratoryjną, zlecając oznaczenie stężenia N-końcowego propeptydu natriuretycznego typu B (NT-proBNP, N-terminal B-type natriuretic propeptide), które wyniosło 3740 pg/ml. Na podstawie uzyskanych wyników badań oraz obrazu klinicznego zmodyfikowano wstępne rozpoznanie, stawiając ostateczną diagnozę zespołu takotsubo. W leczeniu stosowano kwas acetylosalicylowy w dawce $75 \mathrm{mg} /$ dobę, bursztynian metoprololu w dawce $25 \mathrm{mg} /$ dobę, $20 \mathrm{mg} /$ dobę atorwastatyny oraz ramipril w dawce $2,5 \mathrm{mg} /$ dobę.

W wykonywanych w kolejnych dniach hospitalizacji zapisach EKG stwierdzono stopniową normalizację krzywej (ryc. 2). W badaniu echokardiograficznym przed wypisaniem ze szpitala wykazano poprawę kurczliwości wszystkich ścian mięśnia sercowego, brak zaburzeń kurczliwości segmentów koniuszkowych i EF wynoszącą 55\%. Diagnostyka różnicowa pozwoliła wykluczyć jako przyczynę choroby zapalenie mięśnia sercowego i guz chromochłonny. Pacjentkę konsultowano również psychiatrycznie - zalecono dalszą okresową kontrolę w poradni zdrowia psychicznego. Stan kliniczny pacjentki uległ poprawie i po 5 dniach została wypisana do domu z rozpoznaniem zespołu takotsubo.

\section{Omówienie}

U opisanej pacjentki rozpoznano zespół takotsubo - niezbyt często rozpoznawaną jednostkę chorobową. Za takim rozpoznaniem przemawiały: stres jako czynnik inicjujący
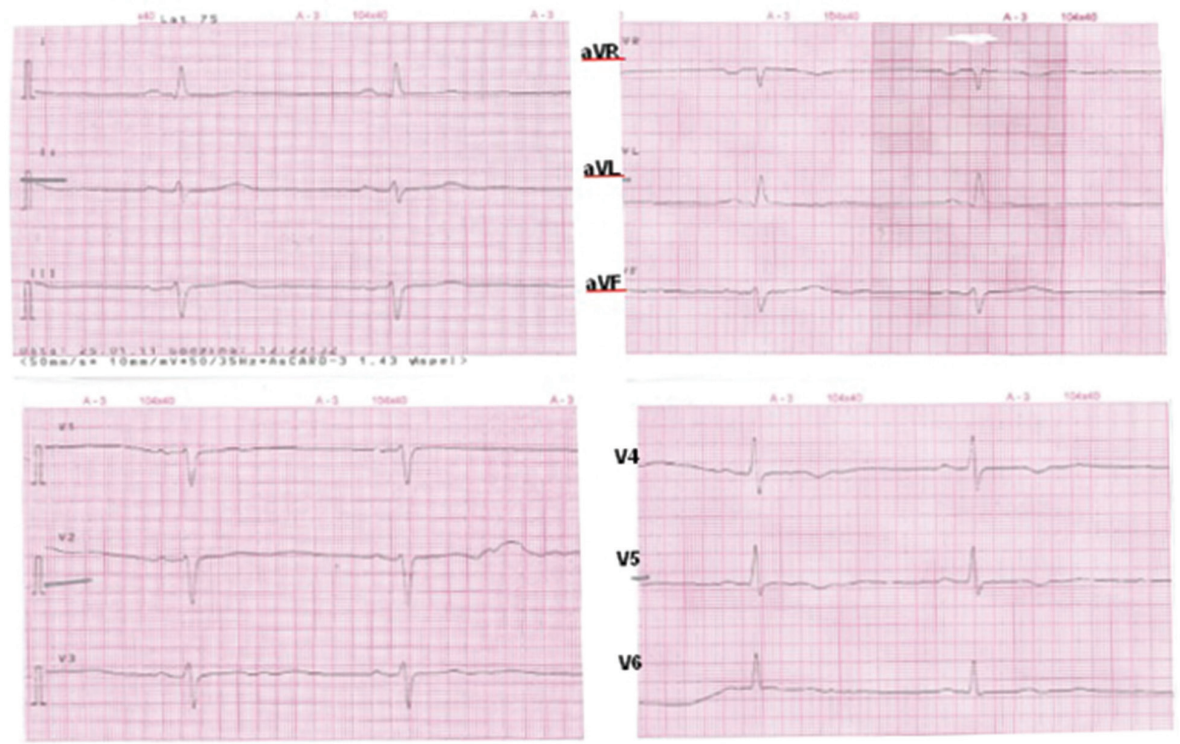

Rycina 2. Zapis elektrokardiograficzny przy wypisaniu pacjentki ze szpitala 
wystąpienie choroby, płeć żeńska, wiek pomenopauzalny, zmiany w EKG z szybką normalizacją zapisu, brak obecności istotnych zwężeń w naczyniach wieńcowych, akineza koniuszka w badaniach obrazowych z ustąpieniem zaburzeń kurczliwości mięśnia sercowego, poprawa parametrów hemodynamicznych w krótkim czasie. Prezentowany przypadek wydawał się typowym przykładem ostrego zespołu wieńcowego z uniesieniem odcinka ST. Wynik koronarografii, która nie wykazała istotnych zwężeń w tętnicach wieńcowych, badanie echokardiograficzne, w którym stwierdzono zaburzenia kurczliwości lewej komory z rozdęciem koniuszka oraz podwyższone stężenie NT-proBNP skłoniły lekarzy do szukania innej przyczyny choroby.

Wysunięto kilka teorii, które mogłyby ją wyjaśniać etiologię takotsubo [4, 5]. Początkowo postulowano teorię zapalną, nie znaleziono jednak dowodów na poparcie tej tezy. Następnie wzięto pod uwagę mechanizm opierający się na skurczu naczyń krwionośnych, jednakże hipoteza ta wydaje się niesłuszna ze względu na różnicę między obszarem unaczynienia poszczególnych tętnic a obszarem podlegającym dysfunkcji w zespole takotsubo. Wysunięto także hipotezę zaburzeń w mikrokrążeniu jednakże i ona, po badaniach metodą Dopplera i echokardiografii z podaniem środka kontrastowego, okazała się nietrafna. Upatrywano również związku między wystąpieniem zespołu a nieprawidłowym metabolizmem kwasów tłuszczowych, redukcją transportu zewnątrzkomórkowego glukozy w okolicy koniuszka serca, predyspozycjami genetycznymi oraz wpływem zmniejszonego stężenia estrogenów na mikrokrążenie wieńcowe. Żadna z tych teorii nie wyjaśniała w pełni patogenezy zespołu. Jedną z aktualnie głoszonych hipotez jest teoria uwzględniająca toksyczny wpływ amin katecholowych na mięsień sercowy $[6,7]$. Prowadzą one do rearanżacji mikroarchitektoniki mięśnia sercowego poprzez jego nadmierną stymulację. Te zmiany, z kolei, mogą się przyczynić do zaburzeń ciśnienia wewnątrzkomorowego i balonowatego rozdęcia koniuszka mięśnia sercowego. W związku z tym, że obszar koniuszkowy serca ma szczególnie dużo receptorów dla katecholamin, jest możliwe, że nadmierna stymulacja katecholaminergiczna może wybiórczo ogłuszać budujące go kardiomiocyty. Ponadto bierze się pod uwagę możliwość toksycznego oddziaływania jonów wapnia, uwolnionych ze zbiorników siateczki śródplazmatycznej wskutek działania amin katecholowych. Mechanizm ten może tłumaczyć wpływ przewlekłego i ostrego stresu jako czynników mogących być przyczyną rozwoju tego rodzaju kardiomiopatii.

Obraz kliniczny jest dość podobny do obrazu ostrego zespołu wieńcowego. Większość pacjentów uskarża się stenokardię skojarzoną z niedawno przeżywanym silnym stresem. W zapisie EKG najczęściej widoczne są: uniesienie lub obniżenie odcinka ST, ujemne załamki T, poza tym rzadziej obecność nowego patologicznego załamka Q, wydłużony odstęp QT, nowo powstały blok prawej lub lewej odnogi pęczka Hisa. Zmiany te szybko ulegają normalizacji. Markery martwicy mięśnia sercowego moga w pozostawać normie lub być nieznacznie podwyższone [8]. W koronarografii zwykle nie udaje się wykazać istotnych hemodynamicznie zmian. Echokardiografia uwidacznia zaburzenia kurczliwości z charakterystyczną dyskinezą lub akinezą koniuszka i środkowej części lewej komory oraz hiperkinezę części podstawnej [9]. Frakcja wyrzutowa jest zwykle obniżona. Charakterystyczne jest to, że zaburzenia hemodynamiki serca szybko ulegają poprawie, czemu towarzyszy poprawa samopoczucia pacjenta.

Obecnie do rozpoznania zespołu takotsubo stosuje się zmodyfikowane kryteria Mayo Clinic, które obejmują przejściowe zaburzenia kurczliwości lewej komory wykraczające poza obszar unaczynienia jednej tętnicy wieńcowej, przemijające zmiany o charakterze świeżego niedokrwienia w EKG, ewentualny wzrost stężenia markerów nekrotycznych oraz wykluczenie innych chorób mogących być przyczyną stanu pacjenta. Do dziś nie sformułowano ścisłych algorytmów leczenia tego takotsubo. Sugeruje się postępowanie według wytycznych dla ostrego zespołu wieńcowego [10].

Rokowanie u pacjentów z zespołem takotsubo jest pomyślne, mimo że niejednokrotnie przebiega on z towarzyszącą ostrą niewydolnością serca i zagrażającymi życiu arytmiami. Śmiertelność szpitalna wynosi 1,1\% i wiąże się z powikłaniami zespołu dotyczącymi układu sercowo-naczyniowego. U niewielkiego odsetka pacjentów możliwy jest nawrót choroby.

\section{Konflikt interesów}

Autorki nie zgłaszają konfliktu interesów. 


\section{Abstract}

Takotsubo cardiomiopathy is a rare, very interesting disease which aetiology stays unclear. It manifests with a typical stenocardia associated with a chronic and acute stress. It affects most commonly white female in a perimenopausal age. Diagnosis is based on a quite fast disappearing typical changes showed in electrocardiography and echocardiography associated with a normal view of coronary arteries in angiography. Prognosis is usually successful.

Key words: cardiomiopathy, takotsubo, stress

(Folia Cardiologica 2015; 10, 5: 370-373)

\section{Piśmiennictwo}

1. Kurisu S., Sato H., Kawagoe T. i wsp. Tako-tsubo-like left ventricular dysfunction with ST-segment elevation: a novel cardiac syndrome mimicking acute myocardial infarction. Am. Heart J. 2002; 143: 448-455.

2. Grabowski M., Karpiński G., Kochamn J. i wsp. Zespół balotującego koniuszka u 57-letniej chorej w trakcie premedykacji do znieczulenia ogólnego. Kardiol. Pol. 2006; 64: 1110-1112.

3. Amaya K., Shirai T., Kodama T. i wsp. Ampulla cardiomyopathy with delayed recovery of microvascular stunning: a case report. J. Cardiol. 2003; 42: 183-188.

4. Pawłowski T., Kukla P., Młotek M. i wsp. Przemijające zaburzenia kurczliwości lewej komory - kardiomiopatia tako-tsubo: nowa jednostka nozologiczna w kardiologii. Kardiol. Pol. 2007; 65: (supl. 4.): 431-445.

5. Uznańska B., Plewka M. Zespół takotsubo; obraz kliniczny, patogeneza i leczenie. Forum Kardiol. 2005; 10: 107-110.
6. Wittstein I.S., Thiemann D.R., Lima J.A. i wsp. Neurohumoral features of myocardial stunning due to sudden emotional stress. N. Engl. J. Med. 2005; 352: 539-548.

7. Kręcki R., Plewka M., Krzemińska-Pakuła M. i wsp. 49-letnia pacjentka z kardiomiopatią stresową tako-tsubo. Pol. Przegl. Kardiol. 2006; 8: 219-222.

8. Yamashita E., Numata Y., Sakamoto K. i wsp. Clinical analysis of 21 patients with so-called takotsubo like cardiomyopathy. Heart 2003; 35: 379-385.

9. Jabłoński M., Rychter M., Król A. i wsp. Zespół balotującego koniuszka. Cardiovasc. Forum 2006; 11: 99-102.

10. Sharkey S.W., Lesser J.R., Zenovich A.G. i wsp. Acute and reversible cardiomyopathy provoked by stress in women from the United States. Circulation 2005; 111: 472-479. 